\title{
Alternative Isoforms of the mi Transcription Factor (MITF) Regulate the Expression of mMCP-6 in the Connective Tissue-Type Mast Cells Cultured with Stem Cell Factor
}

Sun-Hee Lee, Xiu-Ying Guan and Dae-Ki Kim*

Department of Immunology, Chonbuk National University Medical School, Jeonju, Jeonbuk 561-180, Korea

Received October 1, 2008 /Accepted October 23, 2008

\begin{abstract}
$m i$ transcription factor (MITF) is important in regulating the differentiation of mast cells. In particular, MITF regulates the transcription of the mouse mast cell-specific serine protease (mMCP)- 6 gene, which is generally expressed by the connective tissue-type of mast cells. In this study, we investigated alternative isoforms of MITF that regulate transcription of the mMCP-6 gene in bone marrow-derived cultured mast cells in mice. The expression of MITF isoforms was examined by RT-PCR. We observed that MITF-A, -E, -H and -Mc were expressed by mucosal-type mast cells cultured in the presence of IL-3, whereas the connective tissue-type mast cells cultured in the presence of stem cell factor (SCF) expressed MITF-A. Overexpression of MITF isoforms increased luciferase activity through the mMCP-6 promoter in NIH-3T3 cells and elevated the level of mMCP-6 expression in the MC/9 mast cell line. Moreover, mMCP-6 expression in mast cells was significantly inhibited by the depletion of MITF. The transcriptional activity and DNA binding of MITF-A was comparable to that of MITF isoforms, including MITF-E, -H, and -Mc. Our results therefore suggest that MITF-A may be an important isoform of MITF in regulating the transcription of mMCP-6 in mouse connective tissue mast cells.
\end{abstract}

Key words : $m i$ transcription factor, MITF-A, mMCP-6, mast cells, stem cell factor

\section{Introduction}

Mast cells play a crucial role in the development of inflammation and allergic responses. The multivalent binding of an antigen to FceRI-bound IgE triggers the activation of mast cells and subsequently leads to the secretion of granules including mouse mast cell-specific serine proteases (mMCPs) and histamine $[17,28]$. In mice, mast cells express a family of mMCPs such as tryptases and chymases. Members including mMCP-1, -2, -4, -5 and -9 are chymases, while mMCP-6 and mMCP-7 are tryptases [14]. Each family of mMCPs exhibits a tissue-specific distribution. In particular, mMCP-6 is highly expressed in connective tissue mast cells but not in mucosal mast cells [22]. Members of mMCP-1 and -2 are restricted to mucosal mast cells [2,8]. When bone marrow-derived cultured mast cells (CMCs) and peritoneal mast cells were injected into the stomach walls of mast cell-deficient mice, the mMCPs expression pattern of the mast cells in the mucosa and muscularis propria resembled that of mast cells in the stomach of intact mice [12]. These observations suggest that gene expression

\section{*Corresponding author}

Tel : +82-63-270-3080, Fax : +82-63-855-6807

E-mail : daekim@chonbuk.ac.kr of mMCPs is regulated by the local environment.

The mi locus of mice encodes the microphthalmia-associated transcription factor (MITF) gene which is part of the basic/ helix-loop-helix/leucine zipper (b-HLH-Zip) transcription factor. The b-HLH-Zip proteins, including MITF, recognize the CANNTG motifs in the promoter region of target genes. To date, eight isoforms of MITF are known; they are MITF-A [1], -C [3], -Mc [26], -H [23], -M [6,27], -E [19], -D [25], -J [5]. These isoforms have common transcription activation and DNA binding domains, but differ in the N-terminal amino acids encoded by the exon 1 . For most isoforms, the initial exon is spliced onto the latter part of exon 1 and then on to the common exons 2-9, which encode the functionally important motifs, including b-HLH-Zip, transactivation domains, and various phosphorylation consensus sequences. However, whether these MITF isoforms confer distinct properties on each protein is not known. MITF-A is expressed widely in the retinal pigment epithelium to regulate these formations [29]. MITF-M is restricted to neural crest-derived melanocytes and is absolutely required for the development of these cells [4].

It is known that mMCP-6 may be important in mast cell-mediated inflammatory reactions [13,21]. A recent study has demonstrated that MITF increased the tran- 
scription activity of the mMCP-6 gene through binding to two motifs [15]. mMCP-6 is one of the tryptases that is constitutively present in skin mast cells of mice. We have shown that the ability of MITF to regulate mMCP-6 expression is dependent on the activation of mast cells with stem cell factor (SCF) to induce the differentiation of the connective tissue-type mast cells [8]. However, MITF isoforms expressed by the connective tissue-type mast cells remain unclear. In the present study, we demonstrate the profile of MITF isoforms expressed in cultured mast cells and their ability to regulate the transcription of the mMCP-6 gene.

\section{Materials and Methods}

\section{Cell culture}

Bone marrow cells derived from C57BL/6 mice (Samtaco animal, Gyunggido, Korea) were cultured in $\alpha$ minimal essential medium ( $\alpha$-MEM; Invitrogen, Carlsbad, CA) containing 10\% FBS (Hyclone, Logan, UT), 30\% WEHI3-cultured condition medium, $50 \mu \mathrm{M}$ 2-mercaptoethanol and $100 \mathrm{U} / \mathrm{ml}$ penicillin-streptomycin (Sigma, St. Louis, MO) for 3 weeks to establish the CMCs. The purity of mast cells by toluidine blue staining was more than 95 \%. MC/9 mast cell lines were provided by Dr. Y. Kitamura (Osaka University, Japan). For the experiments, CMCs and $\mathrm{MC} / 9$ were grown in $\alpha-\mathrm{MEM}+10 \%$ FBS in the presence of $100 \mathrm{ng} / \mathrm{ml}$ recombinant mouse SCF or $50 \mathrm{ng} / \mathrm{ml} \mathrm{IL-3}$ (R\&D Systems, Minneapolis, MN). NIH-3T3 fibroblasts were maintained in Dulbecco's modification of Eagle's medium (DMEM; Invitrogen) containing 10\% FBS and 100 $\mathrm{U} / \mathrm{ml}$ penicillin-streptomycin.

\section{Reverse transcriptase polymerase chain reaction (RT-PCR)}

Total RNA was extracted from cells using Trizol reagent (Invitrogen). For cDNA synthesis, RNA ( 2 or $0.2 \mu \mathrm{g}$ ) was reverse-transcribed for $1 \mathrm{hr}$ at $42^{\circ} \mathrm{C}$ using the superscript One-Step RT-PCR kit (Invitrogen) according the manufacturer's instruction. One microliter of synthesized cDNAs was amplified in a PCR mixture containing Taq DNA polymerase (Invitrogen) and each pair of specific sense and antisense primers (Bioneer, Daejeon, Korea), as described in Table 1. PCR amplification was performed as follows: denaturation $\left(94^{\circ} \mathrm{C}, 30 \mathrm{sec}\right)$, annealing $\left(58^{\circ} \mathrm{C}, 30\right.$ $\mathrm{sec})$, and extension $\left(72^{\circ} \mathrm{C}, 50 \mathrm{sec}\right)$. The PCR products were
Table 1. The oligonucleotides used for PCR amplification

\begin{tabular}{cll}
\hline & Primer Sequence & $\begin{array}{l}\text { PCR } \\
\text { product }\end{array}$ \\
\hline $5^{\prime}$-Primers & & \\
MITF-A & GGAAGGCGGGCAAGAGGGAGTCAT $791 \mathrm{bp}$ \\
MITF-B & GAGTGCCATGCCGTGCCTTGAT & $438 \mathrm{bp}$ \\
MITF-C & TTTTCCCACCAGCTGATTCCTCTA & $742 \mathrm{bp}$ \\
MITF-D & GGGACCTGACAGGCTCTGAA & $687 \mathrm{bp}$ \\
MITF-E & GGAAGATTAAGCCCAGTGAGGTT & $744 \mathrm{bp}$ \\
MITF-H & GATGGAGGCGCTTAGATTTGAGAT & $722 \mathrm{bp}$ \\
MITF-M & CCTTCTTTATGCCGGTCGCTCTTC & $555 \mathrm{bp}$ \\
MITF-Mc & ACACAAGCCCTACCTCAGAACC & $689 \mathrm{bp}$ \\
MITF-J & CCGTGTCTCTGGGCATCTGAAG & $745 \mathrm{bp}$ \\
GAPDH-Fw & TGCACCACCAACTGCTTAG & $117 \mathrm{bp}$ \\
3'-Primers $^{\prime}$ & & \\
MITF-Rv & CGGGTAACGTATTTGCCATTTG & \\
GAPDH-Rv & GGATGCAGGGATGATGTTC & \\
\hline
\end{tabular}

electrophoresed in 1.2\% agarose gel in 1xTAE buffer and photographed under a UV lamp.

\section{Staining of mast cells}

Cytospin preparations of cells were fixed with Carnoy's solution containing acetic acid, chloroform and ethanol, and than stained with alcian blue or berberine sulfate (Sigma) for $30 \mathrm{~min}$, as described previously [18]. The alcian blue-positive cells were observed under a light microscope, and the berberine sulfate-positive mast cells were observed under a fluorescence microscope.

\section{Construction of expression and reporter plasmids}

cDNA of the MITF isoforms was prepared from the cultured mast cells by RT-PCR and inserted into a TOPO-TA cloning vector (Invitrogen). The plasmids were digested with EcoRI restriction enzymes and then subcloned into pZeoSV2(+) mammalian expression vector (Invitrogen). The sequence of cDNA was identified by sequencing analysis. For the reporter plasmid, the mMCP-6 promoter region between nt -191 and +26 was constructed as described previously [15] and inserted into pGL3-basic vector (Promega, Madison, WI).

\section{Transfection and luciferase activity assay}

The expression $(0.5$ or $2 \mu \mathrm{g})$ and reporter plasmids $(2 \mu \mathrm{g})$ were cotransfected into NIH-3T3 cells $\left(0.5 \times 10^{6}\right.$ in a $6 \mathrm{~cm}$ dish) by a transit-LT1 transfection reagent (Mirus, Pittsburgh, PA). Cells were harvested $48 \mathrm{hr}$ after transfection and lysed with a luciferase lysis reagent (Promega). Soluble extracts were assayed for luciferase activity using 
a luminometer LB96P (Berthold GmbH, Wilbad, Germany). Luciferase activity was normalized by $\beta$-galactosidase and total protein concentration. Each luciferase activity is shown as a relative value calculated with reference to a control expression vector. The sequences of MITF-A siRNA (5'-GCT GCA GGC AGC CCA GTT C-3') and control siRNA (5'-CTA ACG TAC GGA TCT AAC T-3') were designed using a BLOCK-iT ${ }^{\mathrm{TM}}$ RNAi Designer (Invitrogen) and synthesized by a LineSilence ${ }^{\mathrm{TM}}$ complete RNAi kit (Allele Biotech Inc. San Diego, CA).

\section{Tryptase activity assay}

Cells were sonicated in 10 volumes of $20 \mathrm{mM}$ Na-phosphate buffer ( $\mathrm{pH}$ 7.4). After centrifuging, the supernatants were used as extract-containing tryptase. The enzyme activity of tryptase was determined using the substrate tosyl-gly-pro-lys-pNA (Sigma Co.) containing $50 \mu \mathrm{g} / \mathrm{ml}$ heparin. Samples were incubated in a reaction buffer mix for $2 \mathrm{hr}$ at $37^{\circ} \mathrm{C}$, and then the OD was read at $405 \mathrm{~nm}$ in a microplate reader.

\section{Western blot analysis}

Cells were lysed in ice-cold lysis buffer (iNtRON Biotech, Korea) for $20 \mathrm{~min}$ and centrifuged $(12,000 \mathrm{~g})$ for $20 \mathrm{~min}$. The protein concentrations in cell extracts were measured using a bicinchoninic acid. Lysates $(25 \mu \mathrm{g})$ were separated by $10 \%$ SDS-PAGE and transferred to PVDF membranes. After blocking with $5 \%$ skimmed milk in $1 \times$ PBS for $1 \mathrm{hr}$, the membranes were incubated with an anti-MITF polyclonal antibody (N-15, Santa Cruz Biotech., Santa Cruz, CA) at $4^{\circ} \mathrm{C}$, washed in TBS containing 0.1\% Tween 20, and incubated with HRP-conjugated donkey anti-goat IgG polyclonal antibody for $45 \mathrm{~min}$. Finally, proteins were visualized using an enhanced chemiluminescence WB detection kit (Amersham Pharmacia Biotech).

\section{Electrophoretic mobility gel shift assay (EMSA)}

The fusion protein of MITF was produced using the TNT® T7 Quick Coupled Transcription/Translation System (Promega, Madison, WI) according the manufacturer's instruction. Oligonucleotide 5'-CCACCGTGTGACCTGTGG TCATCA was used as a probe. The probe was labeled with $\alpha-\left[{ }^{32} \mathrm{P}\right]-\mathrm{dCTP}$ by Taq polymerase. DNA-binding assays were performed in a $20 \mu \mathrm{l}$ reaction mixture containing $10 \mathrm{mM}$ Tris-HCl (pH 8.0), 1 mM EDTA, $75 \mathrm{mM} \mathrm{KCl}, 1 \mathrm{mM}$ dithiothreitol, 4\% Ficoll type 400, $50 \mathrm{ng}$ of poly (dI-dC), $25 \mathrm{ng}$ of labeled DNA probe, and $10 \mu \mathrm{g}$ of MITF fusion protein. After incubation at room temperature for $15 \mathrm{~min}$, the reaction mixture was subjected to electrophoresis in a $5 \%$ polyacrylamide gel in $0.25 \times \mathrm{TBE}$ buffer $(\mathrm{pH}$ 8.3). The polyacrylamide gels were dried on Whatman 3MM paper (Whatman, Maidstone, UK) and subjected to autoradiography.

\section{Statistical analysis}

Data from the experiments were described to mean \pm S.E.M. Statistical significance was determined using the Student's $t$-test to express the difference between groups. All $p$-values $<0.05$ were considered to reflect a statistically significant difference.

\section{Results}

Expression of MITF isoforms in the cultured mast cells derived from bone marrow

We examined the expression of MITF isoforms in the cultured mast cells (CMCs). CMCs were used 3 weeks after the initiation of the culture because the purity of mast cells reached up to $95 \%$ at this time judging by alcian blue staining. CMCs were cultured for 4 days in the complete medium containing IL-3 or SCF to obtain the mucosal type or connective tissue type, respectively. To identify the phenotype of mast cells, CMCs were stained with berberine sulfate. RT-PCR was performed to estimate the RNA expression levels of MITF isoforms using specific primers (Table 1). The mucosal-type CMCs expressed the transcripts of various MITF isoforms, such as MITF-A, -E, -H, and $-\mathrm{Mc}$ (Fig. 1). However, the connective tissue type CMCs established with SCF showed the expression of MITF-A transcripts, while the transcripts of other isoforms were barely detectable (Fig. 2).

\section{Transactivation of the mMCP- 6 gene by MITF-A}

It has been reported that MITF is an essential transcription factor for the expression of the mMCP-6 gene [20]. We examined whether MITF-A overexpression in the connective tissue type CMCs affects with the transactivation of the mMCP- 6 gene by a luciferase activity assay. To compare the transcriptional activity of MITF-A to that of other isoforms, the expression plasmids of MITF-E, $-\mathrm{H}$ or -Mc were cotransfected with a reporter plasmid comprising the mMCP-6 promoter region into NIH-3T3 cells. A significant 


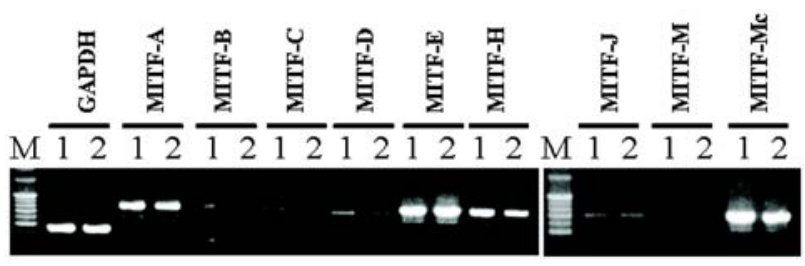

Fig. 1. Expression of MITF isoforms in mucosal-type mast cells cultured with IL-3. Total RNA was extracted from CMCs cultured with IL-3-containing medium for 3 weeks. The RNA expression of MITF isoforms was analyzed by RT-PCR. 1 and 2 indicate the two separate experiments; $\mathrm{M}, 1 \mathrm{~kb}$ DNA marker. PCR products were electrophoresed in $1.2 \%$ agarose gel.

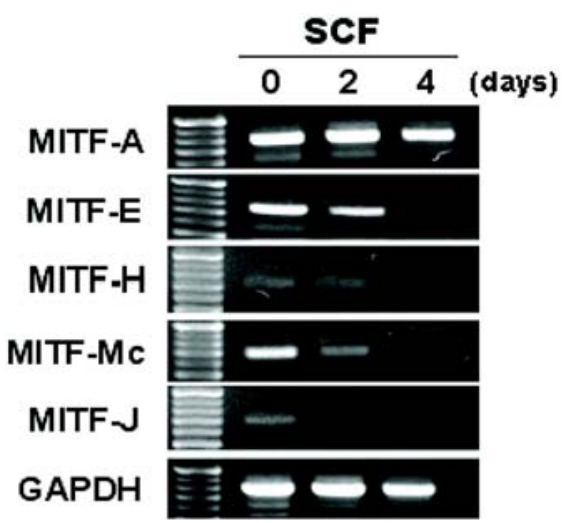

Fig. 2. Expression of MITF isoforms in connective tissue-type mast cells cultured with SCF. CMCs were cultured with SCF for the indicated times before total RNA extraction. The expression of their mRNAs was analyzed by RT-PCR.

increase in luciferase activity was observed in all transfectants overexpressing MITF-A, -E, -H, or -Mc (Fig. 3).

Next, to examine DNA binding activity of MITF-A, we performed EMSA using the oligonucleotide containing GACCTG motif, which represents a part of mMCP-6 promoter region, as a probe. When MITF-A fusion protein was incubated with the probe, DNA-protein complexes were formed in all MITF isoforms. The DNA binding of MITF-A was abolished by the excess amount of the nonlabeled oligonucleotide as a competitor (Fig. 4). However, we observed that a specific DNA/protein complex was barely detectable when nuclear extracts of CMCs were used (data not shown).

The level of tryptase was increased by MITF-A and decreased by introducing MITF siRNA in MC/9 cells

To examine the effect of transcriptional activity of MITF-A on mMCP-6 expression in mast cells cultured with

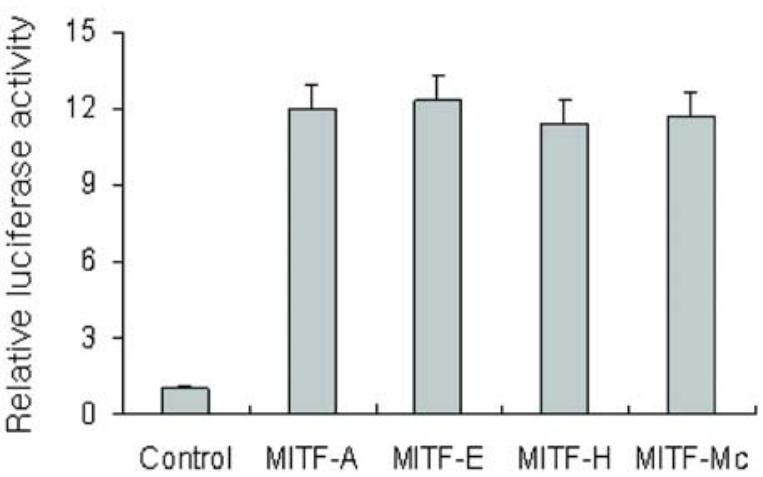

Fig. 3. Transactivation of mMCP-6 promoter by MITF isoforms in NIH-3T3 cells. Expression vectors for MITF-A, -E, $-\mathrm{H}$, and $-\mathrm{Mc}(2 \mu \mathrm{g})$ were used as the effector plasmids. Each effector plasmid was cotransfected with a reporter plasmid containing mMCP-6 promoter into NIH-3T3 cells. The transfectants were incubated and harvested for a luciferase activity assay. Values are presented as relative luciferase activity.

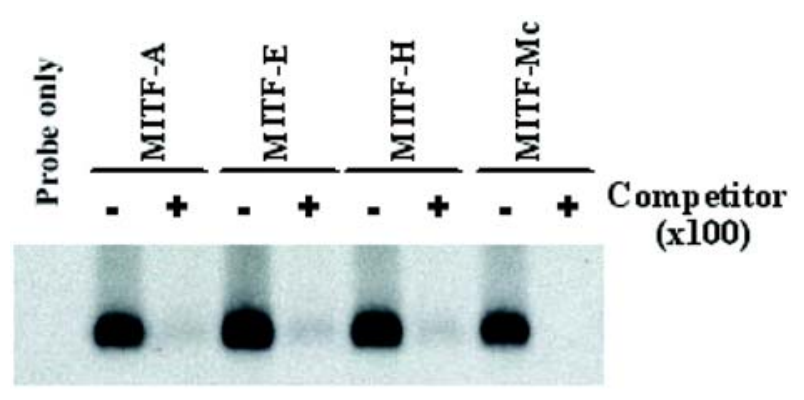

Fig. 4. DNA binding activity of the fusion proteins of MITF isoforms. The synthesized fusion protein of MITF-A, $-\mathrm{E},-\mathrm{H}$, or $-\mathrm{Mc}$ was reacted with the labeled oligonucleotide containing the MITF binding motif. A single retarded band was detected by GMSA. An excess amount of nonlabeled oligonucleoride was added as a competitor.

SCF, we transfected the expression vector MITF-A into the $\mathrm{MC} / 9$ mast cell line. We also transfected the expression vector MITF-E, $-\mathrm{H}$, or $-\mathrm{Mc}$ which are expressed in mucosal type CMCs, to compare their transcriptional activity. The overexpression of MITF-A increased the luciferase activity through the mMCP- 6 promoter, and the level of its expression by MITF-A was comparable to that of MITF-E, -H, or -Mc (Fig. 5A). Moreover, the tryptase activity in $\mathrm{MC} / 9$ cells was increased by overexpression of all isoforms as well (Fig. 5B).

We next examined whether the depletion of MITF-A attenuated the expression of mMCP-6 in MC/9 cells cultured in a medium containing SCF. When the MITF-A siRNA $(0.2$ or $2 \mu \mathrm{g})$ or control siRNA $(2 \mu \mathrm{g})$ was transfected into 
(A)

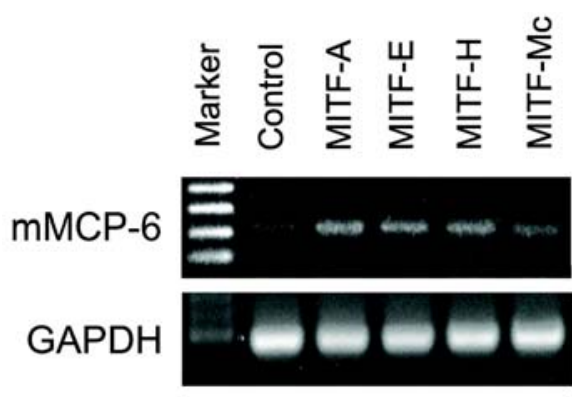

(B)

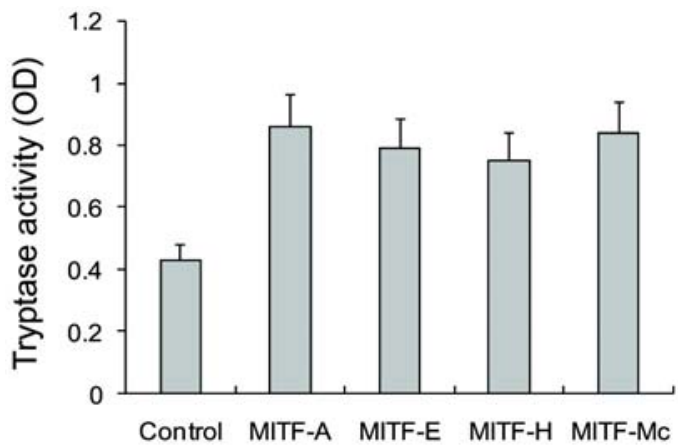

Fig. 5. Upregulation of mMCP-6 expression and tryptase activity by overexpression of MITF isoforms in MC/9 mast cells. (A) The expression plasmids of MITF-A, -E, - $\mathrm{H}$, or -Mc were transfected into MC/9 cells. Empty plasmid was used as negative control. After incubation for $48 \mathrm{hr}$, total RNAs were extracted to detect the mMCP-6 mRNA by RT-PCR. (B) The transfectants were homogenized to analysis the tryptase activity of $\mathrm{mMCP}-6$. Tryptase activity assay was performed by precision microplate reader and the data represent the mean $\pm \mathrm{SE}$ of three experiments.

MC/9 cells, we observed that the expression of MITF protein was significantly reduced in a dose-dependent manner (Fig. 6A). Moreover, the tryptase activity was subsequently decreased by transfection of MITF siRNA (Fig. 6B).

\section{Discussion}

MITF has been reported to regulate the development of mast cells as well as melanocytes. In a recent study, the expression of the mMCP- 6 gene was deficient in mi/mi mice-derived CMCs expressing mutant MITF [15]. The overexpression of wild type MITF but not mutant MITF was able to transactivate the mMCP-6 promoter through binding to GACCTG and CANNTG motifs. This implies that MITF plays an essential role in the transcription of mMCP-6 [21]. In this study, we demonstrated that MITF-A is a major isoform that regulates $\mathrm{mMCP}-6$ expression in mouse mast cells. The connective tissue-type mast cells
(A)

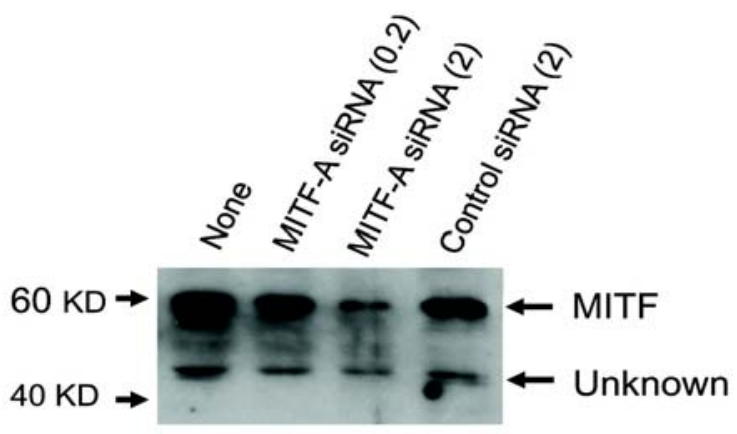

(B)

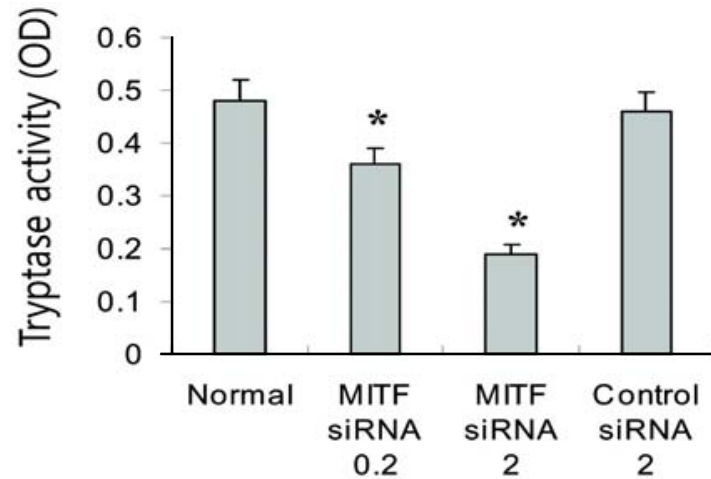

Fig. 6. Downregulation of mMCP-6 expression and tryptase activity by the depletion of MITF in MC/9 mast cells. (A) MITF-A siRNA ( 0.2 and $2 \mu \mathrm{g})$ were transfected into MC/9 cells. Control siRNA ( $2 \mu \mathrm{g})$ was used as a negative control. After incubation for $48 \mathrm{hr}$, Cells were harvested and lysed to identify the expression of MITF by western blot analysis. (B) The transfectants were homogenized to analyze the tryptase activity of mMCP-6. A tryptase activity assay was performed by a precision microplate reader and the data represent the mean \pm SE of three experiments. ${ }^{*} p<0.05$.

present in skin and muscle strongly expressed MITF-A, and the DNA binding activity of MITF was comparable to that of other MITF isoforms. Although all MITF isoforms have transcriptional activity that leads to the expression of the mMCP-6 gene, MITF-A was constitutively expressed in both mucosal and connective tissue-type mast cells. In particular, the overexpression of MITF-A increased MMCP-6 expression and tryptase activity by $\mathrm{MC} / 9$ cells cultured with SCF. It suggests that MITF-A is critically involved in the development of mast cells to connective tissue types expressing mMCP-6.

Mast cells are known as effector cells in inflammatory reactions because they secrete various chemical mediators such as histamine, serotonin, chymase, tryptase, and eicosanoids. When the MC is challenged by an external stimulus, it may respond by degranulation [11,24]. In this process, a number of powerful inflammatory mediators are 
released. Tryptase is known to regulate allergic and inflammatory responses, including recruitment of neutrophils, Th2 cells, and basophils [12,21]. The mast cells in mouse skin express abundant tryptase mMCP-6. CMCs derived from bone marrow of transgene-insertional vga9/ vga9 mutant mice, which do not express MITF owing to insertion of the gene in the promoter region, showed abnormal phenotypes including deficiencies in expression of mMCP-4, $-6,-7$, granzyme B, prostaglandin D2, and tryptophan hydroxylase $[6,7,9,16,20]$. Our finding supports the idea that MITF-A is involved in regulating the function of mast cells.

Our results have shown that MITF-A may be a major isoform in regulating $\mathrm{mMCP}-6$ expression in mouse mast cells. Stimulation of CMCs by SCF elicits the expression of MITF-A and subsequently mMCP-6. However, although the importance of MITF-A in the expression of mMCP-6 has been demonstrated, no one has investigated the transcriptional mechanism generating MITF-A in mast cells. Such identification would promote further analysis of the development of mast cells and would be useful in evaluating the physiological roles of mast cell-derived proteases.

\section{Acknowledgement}

This work was supported by the Korea Research Foundation Grant funded by the Korean Government (MOEHRD)"(KRF-2005-003-E00041).

\section{References}

1. Amae, S., N. Fuse, K. Yasumoto, S. Sato, I. Yajima, H. Yamamoto, T. Udono, Y. K. Durlu, M. Tamai, K. Takahashi and S. Shibahara. 1998. Identification of a novel isoform of microphthalmia-associated transcription factor that is enriched in retinal pigment epithelium. Biochem. Biophys. Res. Commun. 247, 710-715.

2. Friend, D. S., N. Ghildyal, K. F. Austen, M. F. Gurish, R. Matsumoto and R. L. Stevens. 1996. Mast cells that reside at different locations in the jejunum of mice infected with Trichinella spiralis exhibit sequential changes in their granule ultrastructure and chymase phenotype. J. Cell Biol. 135, 279-290.

3. Fuse, N., K. Yasumoto, K. Takeda, S. Amae, M. Yoshizawa, T. Udono, K. Takahashi, M. Tamai, Y. Tomita, M. Tachibana and S. Shibahara. 1999. Identification of a distal enhancer for the melanocyte-specific promoter of the MITF Gene. J. Biochem. 126, 1043-1051.

4. Goding, C. R. 2000. Mitf from neural crest to melanoma: signal transduction and transcription in the melanocyte lineage. Genes Dev. 14, 1712-1728.

5. Hershey, C. L. and D. E. Fisher. 2005. Genomic analysis of the microphthalmia locus and identification of the MITF-J/Mitf-J isoform. Gene 347, 73-82.

6. Hodgkinson, C. A., K. J. Moore, A. Nakayama, E. Steingrimsson, N. G. Copeland, N. A. Jenkins and H. Arnheiter. 1993. Mutations at the mouse microphthalmia locus are associated with defects in a gene encoding a novel basic-helix-loop-helix-zipper protein. Cell 74, 395-404.

7. Ito, A., E. Morii, K. Maeyama, T. Jippo, D. K. Kim, Y. M. Lee, H. Ogihara, K. Hashimoto, Y. Kitamura and H. Nojima. 1998. Systematic method to obtain novel genes that are regulated by mi transcription factor: impaired expression of granzyme B and tryptophan hydroxylase in $\mathrm{mi} / \mathrm{mi}$ cultured mast cells. Blood 91, 3210-3221.

8. Jippo, T., K. Tsujino, H. M. Kim, D. K. Kim, Y. M. Lee, Y. Nawa and Y. Kitamura. 1997. Expression of mast-cellspecific proteases in tissues of mice studied by in situ hybridization. Am. J. Pathol. 150, 1373-1382.

9. Jippo, T., Y. M. Lee, Y. Katsu, K. Tsujino, E. Morii, D. K. Kim, H. M. Kim and Y. Kitamura. 1999. Deficient transcription of mouse mast cell protease 4 gene in mutant mice of $\mathrm{mi} / \mathrm{mi}$ genotype. Blood 93, 1942-1950.

10. Kim, D. K. and Y. M. Lee. 2004. Requirement of c-jun transcription factor on the mouse mast cell protease (mMCP)-6 expression in the mast cells. Archi. Biochem. Biophys. 431, 71-78.

11. Kitamura, Y. 1989. Heterogeneity of mast cells and phenotypic change between subpopulations. Annu. Rev. Immunol. 7, 59-76.

12. Lee, Y. M., T. Jippo, D. K. Kim, Y. K. Kitamura, K. Tsujino, E. Morii, H. M. Kim, S. Adachi, Y. Nawa and U. Kitamura. 1998. Alteration of protease expression phenotype of mouse peritoneal mast cells by changing the microenvironment as demonstrated by in situ hybridization histochemistry. Am. J. Pathol. 153, 931-936.

13. McNeil, H. P., R. Adachi and R. L. Stevens. 2007. Mast cell-restricted tryptases: structure and function in inflammation and pathogen defense. J. Biol. Chem. 282, 20785-20789.

14. Miller, H. R. and A. D. Pemberton. 2002. Tissue-specific expression of mast cell granule serine proteinases and their role in inflammation in the lung and gut. J. Immunol. 105, 375-390.

15. Morii, E., T. Tsujimura, T. Jippo, K. Hashimoto, K. Kakebayashi, K. Tsujino, S. Nomura, M. Yamamoto and Y. Kitamura. 1996. Regulation of mouse mast cell protease 6 gene expression by transcription factor encoded by the $\mathrm{mi}$ locus. Blood 88, 2488-2494.

16. Morii, E. and K. Oboki. 2004. MITF Is necessary for generation of prostaglandin D2 in mouse mast cells. J. Biol. Chem. 279, 48923-48929.

17. Nadler, M. J., S. A. Matthews, H. Turner and J. P. Kinet. 2000. Signal transduction by the high-affinity immunoglobulin E receptor Fc epsilon RI: coupling form to 
function. Adv. Immunol. 76, 325-355.

18. Nakano, T., T. Sonoda, C. Hayashi, A. Yamatodani, Y. Kanayama, H. Asai, T. Yonezawa, Y. Kitamura and S. J. Galli. 1985. Fate of bone marrowderived cultured mast cells after intracutaneous, intraperitoneal, and intravenous transfer into genetically mast cell deficient $W W v$ mice: Evidence that cultured mast cells can give rise to both "connective tissue-type" and "mucosal"mast cells. J. Exp. Med. 162, 1025-1043.

19. Oboki, K., E. Morii, T. R. Kataoka, T. Jippo and Y. Kitamura. 2002. Isoforms of mi transcription factor preferentially expressed in cultured mast cells of mice. Biochem. Biophys, Res. Commun. 290, 1250-1254.

20. Ogihara, H., E. Morii, D. K. Kim, K. Oboki and Y. Kitamura. 2001. Inhibitory effect of the transcription factor encoded by the mutant mi microphthalmia allele on transactivation of mouse mast cell protease 7 gene. Blood 97, 645-651.

21. Pejler, G., M. Abrink, M. Ringvall and S. Wernersson. 2007. Mast Cell Proteases. Adv. Immunol. 95, 167-255.

22. Reynolds, D. S., D. S. Gurley, K. F. Austin and W. E. Serafin. 1991. Cloning of the cDNA and gene of mouse mast cell protease-6: transcription by progenitor mast cells and mast cells of the connective tissue subclass. J. Biol. Chem. 266, 3847-3853.

23. Steingrimsson, E. 1994. Molecular basis of mouse microphthalmia (mi) mutations helps explain their developmental and phenotypic consequences. Nat. Genet. 8, 256.
24. Stevens, R. L. and K. F. Austen. 1989. Recent advances in the cellular and molecular biology of mast cells. Immunol. Today 10, 381-386.

25. Takeda, K., K. Yasumoto, N. Kawaquchi, T. Udono, K. Watanabe, H. Saito, K. Takahashi, M. Noda and S. Shibahara. 2002. Mitf-D, a newly identified isoform, expressed in the retinal pigment epithelium and monocyte-lineage cells affected by Mitf mutations. Biochim. Biophys. Acta 1574, 15-23.

26. Takemoto, C. M., Y. J. Yoon and D. E. Fisher. 2002. The identification and functional characterization of a novel mast cell isoform of the microphthalmia-associated transcription factor. J. Biol. Chem. 277, 30244-30252.

27. Tassabehji, M., V. E. Newton and A. P. Read. 1994. Waardenburg syndrome type 2 is caused by mutations in the human microphthalmia (MITF) gene. Nat. Genet. 8, 251-255.

28. Williams, C. M. and S. J. Galli. 2000. The diverse potential effector and immunoregulatory roles of mast cells in allergic disease. J. Allergy Clin. Immunol. 105, 847-859.

29. Yajima, I., S. Sato, T. Kimura, K. Yasumoto, S. Shibahara, C. R. Goding and H. Yamamoto. 1999. An L1 element intronic insertion in the black-eyed white (Mitf ${ }^{\text {mi-bw }}$ ) gene: the loss of a single Mitf isoform responsible for the pigmentary defect and inner ear deafness. Hum. Mol. Genet. 8, 1431-1441.

\section{초록 : SCF에서 배양한 결합조직형 비만세포에서 mMCP-6 발현을 조절하는 MITF 이형체}

이선희 · 관수영 · 김대기*

(전북대학교 의과대학 면역학교실)

$m i$ transcription factor (MITF)는 비만세포의 분화를 조절하는 중요한 전사인자이다. 특히 MITF는 결합조직형 비만세포에서 일반적으로 발현하는 비만세포 특이적 세린 단백분해효소의 일종인 mMCP-6 유전자의 전사를 조 절한다. 본 연구는 마우스 골수유래 배양비만세포에서 mMCP-6 유전자의 전사를 조절하는 MITF이형체를 규명 하였다. MITF 이형체들의 발현은 RT-PCR로 확인하였다. IL-3존재 하에서 배양한 점막형 비만세포들은 MITF-A, $-\mathrm{E},-\mathrm{H}, \mathrm{Mc}$ 등이 발현하였다. 반면에 SCF존재 하에서 배양한 결합조직형 비만세포들은 MITF-A가 발현하였다. MITF이형체를 과발현시키면 NIH-3T3 세포에서 mMCP-6 promoter를 통한 luciferase 활성을 증가시키고, MC/9 비만세포주에서는 증가된 mMCP-6발현을 유도하였다. 더불어 비만세포에서의 mMCP-6 발현은 MITF-A 고갈로 인하여 유의적으로 억제되었다. MITF-A의 전사활성과 DNA결합은 MITF-E, $-\mathrm{H},-\mathrm{Mc}$ 등의 타 이형체들의 결과와 유사하였다. 따라서 본 연구의 결과들은 MITF-A가 마우스 결합조직형 비만세포에서 발현하여 mMCP-6 전사를 조절하는 중요한 이형체임을 제시한다. 